\title{
SOCIOECONOMIC DISPARITY AND POVERTY PROFILES IN OIL PRODUCING RURAL AREAS IN NIGERIA
}

\author{
Inibehe George Ukpong ${ }^{1}$, Mercy Michael Inyeinyang ${ }^{2}$, Abraham Godwin \\ Ominikari $^{1}$ \\ ${ }^{1}$ Department of Agricultural Extension and Management, School of Agricultural Technology, \\ Federal Polytechnic, Ekowe, Bayelsa State, Nigeria. \\ ${ }^{2}$ School of Agriculture, Policy and Development, University of Reading, United Kingdom. \\ Corresponding e-mail: inibeheukpong@gmail.com
}

Citation: Ukpong I.G., Inyeinyang M.M., Ominikari A.G., 2019. Socioeconomic Disparity And Poverty Profiles In Oil Producing Rural Areas In Nigeria, Nigeria. J. Asian Rur. Stud. 3(2): $145-157$

\begin{abstract}
This study examines the disparity in socioeconomic and poverty profiles of people in oil producing rural areas in Nigeria. The study involved a total of 446 respondents selected from fifteen rural communities in the Niger Delta region, where the bulk of Nigeria's crude oil is produced. Inferences were based on the results from simple descriptive analysis involving percentages and cross tabulations. The results indicate a wide disparity in the socioeconomic characteristics and poverty profiles of people in the study areas. In particular, the results suggest poverty prevalence in oil producing rural areas particularly among farmers, fishermen and young people. The results also suggest an obvious impact of oil and gas extraction on agriculture and other traditional sources of livelihood in the rural areas. Thus, a reduction in environmental pollution would help to improve agriculture and other sources of livelihood of the rural people. The study also encourages government support and increased private sector investment in agriculture in the rural areas, while multinational oil companies are encouraged to promote agricultural development through increased financial support for rural farmers, training of the farmers and funding for agricultural research. In addition, the government and multinational oil companies are encouraged to guarantee efficient wealth distribution, provision of employment and sustainable human empowerment through viable skills acquisition programmes for young people in the rural areas.
\end{abstract}

Keywords: Nigeria; Niger delta; Oil Producing Areas; Poverty; Rural Areas

\section{Introduction}

There has been a long history of poverty in rural African communities including Nigeria. As also highlighted by Ukpong et al. (2013), poverty has been a major socioeconomic problem in Nigeria despite abundance of natural endowments; including enormous fertile agricultural lands, as well as rich water and forest resources. One of the unique features of the rural areas in Africa is the large dependency on the natural environment and massive engagement in subsistence agriculture (Ekpebu \& Ukpong, 2012). In Nigeria a large number of rural population depend largely on agriculture (farming) for their livelihood and crude oil has been the main stay of Nigeria's economy over the past three decades (Ukpong et al., 2013). Crude oil contributes the largest percentage proportion of Nigeria's gross domestic product (GDP), but its exploration 
and extraction processes pose major constraints to agriculture and other traditional sources of livelihoods in the rural areas; including fishing and forestry economic activities (Bhau \& Ukpong, 2018).

The irony is that despite engagement in agriculture, rural population in Nigeria still fall among the poorest and food insecure which could be attributed among other reasons to the increasing impacts of crude oil extraction and seeming neglect of the agricultural section after the discovery of crude oil. According to Ukpong \& Obok (2018), farmers in rural Nigerian communities are among the poorest having been affected by the impacts of crude oil extraction. Similarly, Bhau \& Ukpong (2018), reported high vulnerability to the negative environmental impacts of oil and gas extraction among farmers and fishermen in oil producing areas. Thus, improved agricultural development and reduction in environmental pollution will go a long way toward improving the incomes of rural households, improve their livelihoods, alleviate poverty and help solve other socioeconomic problems in the rural areas.

Despite enormous natural resources in the rural areas, oil producing rural communities in Nigeria lack basic social and economic infrastructure which otherwise would help the people improve their livelihood. According to Gibson \& Rozelle (2003) stated that rural development is an important strategy for addressing rural poverty. Fan et al. (2000) also noted that provision of rural infrastructure would promote more employment, hence would lead to poverty reduction, access to cheap food and higher income. As also shared by Idemudia (2010), provision of rural infrastructure by the government and effective delivery of social responsibilities by oil and gas firms operating in the rural areas would help solve the socioeconomic and security challenges in the oil producing areas.

The oil industry was developed from proceeds made from the agricultural sector (Ita et al., 2013), thus in a bid to alleviate poverty and improve the socioeconomic wellbeing in the rural areas, it is important to promote sustainable agricultural development which the country's rural areas have an economic comparative advantage. Notably, majority of the poor population in Nigeria live in the rural areas; where agriculture has been the main source of livelihood and culture of the people (Ukpong,2011; Ekpebu \& Ukpong, 2013). As a major source of livelihood, agriculture is, therefore, expected to enhance poverty reduction in the country; by providing increased income especially for the rural people, as well as promoting improvement in their livelihood.

Also, Nigeria's population is fast growing making the country the world's most populated black nation in the world, and in recent years, there have been high rates of poverty incidence, low life expectancy and poor access to sanitation; unemployment, high inflation and food insecurity in the country (EarthTrends, 2003; FAO, 2010). As applicable in other nations such as China with high population growth, Nigeria's large population further complicates issues of food security and livelihood (Huang \& Ukpong, 2019).

One of the major problems affecting economic development and people's livelihood in the oil producing areas is that of the negative impacts of the oil and gas industry. There is no doubt that the oil and gas industry has been a major source of national revenue and GDP growth in Nigeria. The industry through various corporate social responsibility (CSR) projects have in various ways contributed to employment and rural 
development in the oil producing areas. Nevertheless, the industry remains a big threat to the natural environmental resources which further complicates the poverty profiles of the rural population who largely depend on the natural environment for their livelihood (Adekola et al., 2015; Ekpebu \& Ukpong, 2012). This threat is obvious owing to the fact that oil and gas extraction and transportation are highly entangled with the natural environment, thus exacerbating economic externalities, resource exploitation and destruction of traditional sources of livelihood in the rural areas.

In recent years, several studies have focused on the Niger Delta following the region's potential as the base of Nigeria's crude oil and gas. Ukpong \& Obok (2018), outlined the effects of crude oil extraction on agriculture and people's livelihood, and inferred that farmers and fishermen seem to be the most vulnerable to environmental problems originating from crude oil extraction with farmers incurring greater losses during pipeline explosions and oil spills that pollute and destroy farmlands. According to Bhau \& Ukpong (2019), while acknowledging the economic contributions of the oil and gas industry to rural development and national revenue generation, findings of the study suggest that operations of the industry particularly crude oil extraction and transportation have resulted in resource curse issues which have led to poverty and other socioeconomic issues in oil producing rural areas. Also, findings by Ukpong et al. (2017), indicated a high percentage of respondents with perceived feelings of resource curse paradox about the oil and gas industry with reference to oil producing rural communities in Nigeria, while a publication by Gaughran (2009) suggested that the oil industry might have aggravated poverty due to environmental pollution in the Niger Delta.

Similarly, Chokor (2004), had evaluated the perceptions and responses to the challenges of poverty and environmental resource degradation in oil producing rural areas of the Niger Delta, while Onuaha (2007), noted the obvious nexus between poverty and poor disaster management as a result of oil and gas pipeline vandalism and pipeline explosion in areas of the Niger Delta region where crude oil is being extracted and transported. To address these negativities, Idemudia (2014), emphasised the need for improved corporate social responsibilities among multinational oil companies towards poverty reduction and development of oil producing rural communities in Nigeria. Also, Ukpong (2019), identified poverty as one of the major effects of oil and gas operations in oil producing areas, and suggested that appropriate mitigation measures be taken with reference to environmental laws and global best drilling practices.

These varying indices contribute to the intricacy of socioeconomic profiles of individuals and households in the rural areas with those within oil producing areas being the most vulnerable. Specifically, with a large population in the rural areas being largely dependent on agriculture and the natural environment, this study was framed with the view that crude oil extraction in these areas might affect people's socioeconomic and poverty profiles. Based on this background, this study was designed to draw inferences from the disparity in socioeconomic identities and poverty profiles in oil producing rural areas in Nigeria, with a view to underline the need for significant reduction in environmental pollution, and strategies for achieving sustainable agricultural development to help alleviate poverty and enhance improved livelihoods amongst rural population in Nigeria. 
Also, to complement the findings of the various studies on the subject matter, most of which assessed people's perceptions of the oil industry and applied a variety of quantitative analytical methodologies, this study focused mainly on simple descriptive procedures to draw clearer and succinct inferences on the subject matter.

\section{Method}

The study used a simple descriptive perspective towards making inferences on the disparity in socioeconomic and poverty profiles in the rural areas in Nigeria, this involves percentages and cross tabulations. The study engaged a total of 450 respondents selected from fifteen rural communities in the oil producing areas of the Niger Delta region in Southern Nigeria, with at most thirty (30) people interviewed in each of the fifteen (15) communities. The communities were selected from three (3) states including Akwa Ibom, Bayelsa and Rivers, with at most five (5) communities selected in each of the three states. These include: Akwa Ibom State: Edo, Iko, Mkpanak, Unyenge and Ukpenekang. Bayelsa State: Odi, Imiringi, Etiama, OkotiamaGbarain, and Ogboibiri. Rivers State: Chokota community, Igbo-Etche, Alesa-Eleme, Obigbo, and Biara.

The Niger Delta region is where the bulk of Nigeria's crude oil is being extracted and transported. The oil and gas industry has been the major source of national revenue to the Nigerian economy since the era of 'oil boom' in the 1970s, contributing largely to the country's gross domestic product (GDP) up to this present era. The oil industry was significantly developed in the 1960s from the proceeds accrued from the country's agricultural sector which experienced a boom in export of food and cash crops (Ita et al., 2013). Southern Nigeria, particularly the Niger Delta region located within close proximity to the Gulf of Guinea, has been the primary base of the country's on-shore crude oil and gas reserves (Bhau \& Ukpong, 2018). The suitability of the study area to the subject matter thus, further strengthens the importance of this study as a valuable and valid literary compendium for references and further studies on the issues of poverty and socioeconomic disparity in the oil producing areas.

\section{Results and Discussion}

Without emphasis on complex statistical analysis, this study used simple descriptive statistics to examine the narratives of individual income and its distribution across varying socioeconomic characteristics of the respondents to draw critical inferences. The bench mark of this analysis is based on the current national minimum wage of 30,000.00 Naira (est. 83 USD) proposed by the Nigerian Labour Congress (NLC) in 2018.

\section{Descriptive Statistics}

Out of 450 people contacted, a total of 446 respondents from fifteen rural communities effectively participated in the questionnaire survey. The summary of the descriptive statistics of the respondents is presented in Table 1 below. 
Table 1. Descriptive Statistics

\begin{tabular}{lccccccc}
\hline Characteristic & N & Minimum & Maximum & $\begin{array}{c}\text { Mean } \\
\text { Statistics }\end{array}$ & $\begin{array}{c}\text { Mean } \\
\text { Std. Error }\end{array}$ & $\begin{array}{c}\text { Standard } \\
\text { Deviation }\end{array}$ & Variance \\
\hline Gender & 446 & 0 & 1 & 0.65 & 0.023 & 0.477 & 0.228 \\
Marital Status & 446 & 1 & 4 & 1.83 & 0.035 & 0.737 & 0.543 \\
$\begin{array}{l}\text { Educational } \\
\text { Level }\end{array}$ & 446 & 1 & 4 & 2.98 & 0.050 & 1.047 & 1.096 \\
Family size & 446 & 1 & 10 & 4.08 & 0.107 & 2.254 & 5.081 \\
Monthly & 446 & 750 & 150000 & 23952.35 & 1263.275 & 26678.747 & $7.118 \mathrm{E} 8$ \\
Income & & & & & & & \\
Age (in years) & 446 & 18 & 64 & 40.04 & 0.521 & 11.011 & 121.239 \\
\hline
\end{tabular}

Note: Monthly income is in Nigerian currency (Naira:

As shown in Table 1 above, the mean age of the respondents is 40 years with a minimum age of 18 years and a maximum age of 64 years. The family size of the respondents was between 1 and 10 people, with an average family size of four (4) people.

The monthly income of the respondents in Nigerian Naira ( $N$ ) ranged between $\$ 750.00$ and $\$ 150,000.00$ with an average monthly income of $\$ 23,952.35$, which is below the current minimum wage in the country. The income range of 750 to 150,000 Naira suggests a comparatively wide gap in monthly income which otherwise indicates a wide income inequality among the respondents. It is also important to highlight that income inequality is among the major causes of social crimes including insurgency and conflicts in the Niger Delta (Ukiwo, 2007; Ukpong et al., 2017).

From the results with an average monthly income of $\$ 23,952.35$, it is obvious that the majority of the respondents earn below the maximum wage ( $\$ 30,000.00)$, some of whom are below the poverty line of 1-2 US Dollars per day, confirming conspicuous poverty incidence in the study areas as also reported in the literature by Ukpong et al. (2017). Bhau \& Ukpong (2018), also reported a wide gap of income inequality in the oil producing areas which might be due to high rate of unemployment, and loss of livelihood as a result of the various negative impacts of crude oil extraction on the natural environment and sources of livelihood of the rural people. Similarly, Ukpong \& Obok (2018), opined that farmers in oil producing rural Nigerian communities are among the poorest having been affected by the impacts of crude oil extraction.

Thus, to close the seeming unsurmountable disparity in income regimes and other socioeconomic indices, this study suggests a sustainable improvement in agriculture which has been one of the main traditional sources of livelihood in the rural areas. On the other hand, fishermen in the rural areas can also be empowered with more efficient fishing implements and affordable modern preservation techniques and equipment. Above all, there is a need for a committed effort by all and sundry to stop where possible or significantly reduce environmental pollution in the rural areas. 


\subsection{Distribution of the respondents based on income groups and education levels}

The distribution of the respondents based on income groups and education levels is presented in Table 2 below.

Table 2. Distribution of the respondents based on income groups and education levels

\begin{tabular}{|c|c|c|c|c|c|}
\hline \multirow[b]{2}{*}{ Income group } & \multicolumn{4}{|c|}{ Education levels } & \multirow[b]{2}{*}{ Total } \\
\hline & $\begin{array}{l}\text { No Formal } \\
\text { Education }\end{array}$ & $\begin{array}{c}\text { Completed Primary } \\
\text { school }\end{array}$ & $\begin{array}{c}\text { Completed } \\
\text { Secondary School }\end{array}$ & $\begin{array}{c}\text { Tertiary } \\
\text { Education }\end{array}$ & \\
\hline Less than 10000 & 6.3 & 4.2 & 11.2 & 13.7 & 35.5 \\
\hline $10000-20000$ & 7.2 & 5.4 & 12.6 & 2.2 & 27.4 \\
\hline $21000-30000$ & 0.9 & 2.2 & 7.2 & 3.6 & 13.9 \\
\hline $31000-40000$ & 0 & 0.9 & 1.7 & 2.9 & 5.4 \\
\hline $41000-50000$ & 0 & 0 & 0.7 & 3.4 & 4.1 \\
\hline $51000-60000$ & 0 & 0 & 0.2 & 2.9 & 3.1 \\
\hline $61000-70000$ & 0 & 0 & 0 & 2.4 & 2.4 \\
\hline $71000-80000$ & 0 & 0 & 0.2 & 2.2 & 2.4 \\
\hline $81000-90000$ & 0 & 0 & 0 & 1.8 & 1.8 \\
\hline $91000-100000$ & 0 & 0 & 0 & 2.2 & 2.2 \\
\hline Above 100000 & 0 & 0 & 0 & 1.8 & 1.8 \\
\hline Total & 14.4 & 12.7 & 33.8 & 39.2 & 100 \\
\hline
\end{tabular}

Note: Income figures are in Nigerian currency (Naira). Education levels are in percentage of the respondents

Although research on Chinese agricultural management has been published in various formats, in the current research, in principle, only Japanese papers published on the research site were delimited as analysis subjects. The site contains academic information such as papers, books, magazines, and doctoral dissertations. The site is the most popular database in Japan. We conducted a search on "China agricultural management" as keywords. A total of 152 Japanese papers after 1980 were recorded (Table 1). The literature collection period is limited to 1980 onwards because the early 1980 s were a period of structural change from the People's Commune of China Agriculture (1958-1970) to the family management stage (first half of 1980). As shown in Table 2 above, respondents with tertiary education comparatively dominate higher income groups (that is, above $\$ 30,000.00$ per month benchmark), which suggests that a higher level of education could lead to earning comparatively higher income.

However, there is also high percentage of the respondents with tertiary education within the lowest income groups, with reference to the minimum wage of $\$ 30,000.00$, indicating perhaps a high proportion of low income earners among educated respondents; which further suggests that there are a large number of unemployed educated respondents including graduates with very low paid jobs in the rural areas. Obviously, lack of employment and low income or income inequality suggest the actuality of poverty, which has been identified among the major causes of insurgency and other social crimes in the oil producing areas (Ukiwo, 2007; Oyefusi, 2008).

The presence of educated people in the rural areas may not be unconnected with the fact that most unemployed educated people return to the rural areas to avert high cost of living in the urban cities. In view of these, there is a need for a sustainable strategy for 
creating employment in the rural areas, which might include skill acquisition programmes which would make the people not only employable but also helping to create employment for themselves and others.

\subsection{Distribution of the respondents based on income groups and age}

Table 3 below presents the distribution of respondents based on income groups and age categories.

Table 3 Distribution of the respondents based on income groups and age

\begin{tabular}{cccccccc}
\hline \multirow{2}{*}{ Income group } & \multicolumn{7}{c}{ Age category } \\
\cline { 2 - 7 } & $\begin{array}{c}\text { Below 20 } \\
\text { years }\end{array}$ & $\begin{array}{c}20-29 \\
\text { years }\end{array}$ & $\begin{array}{c}30-39 \\
\text { years }\end{array}$ & $\begin{array}{c}40-49 \\
\text { years }\end{array}$ & $\begin{array}{c}50-59 \\
\text { years }\end{array}$ & $\begin{array}{c}60 \text { years \& } \\
\text { above }\end{array}$ & Total \\
\hline Less than 10000 & 2 & 12.6 & 9.9 & 6.1 & 4.7 & 0.2 & 35.5 \\
$10000-20000$ & 0.2 & 2.1 & 6.7 & 9.9 & 7.6 & 0.9 & 27.4 \\
$21000-30000$ & 0 & 1.1 & 3.4 & 6.1 & 2.2 & 1.1 & 13.9 \\
$31000-40000$ & 0 & 0.2 & 1.7 & 2.2 & 1.1 & 0.2 & 5.4 \\
$41000-50000$ & 0 & 0 & 0.9 & 2.5 & 0.7 & 0 & 4.1 \\
$51000-60000$ & 0 & 0 & 1.3 & 1.3 & 0.3 & 0.2 & 3.1 \\
$61000-70000$ & 0 & 0 & 1.3 & 1.1 & 0 & 0 & 2.4 \\
$71000-80000$ & 0 & 0 & 1.6 & 0.4 & 0.4 & 0 & 2.4 \\
$81000-90000$ & 0 & 0 & 0.2 & 0.9 & 0.5 & 0.2 & 1.8 \\
$91000-100000$ & 0 & 0 & 0.7 & 1.1 & 0.4 & 0 & 2.2 \\
Above 100000 & 0 & 0 & 0.7 & 0.4 & 0.7 & 0 & 1.8 \\
Total & 2.2 & 16.0 & 28.3 & 32 & 18.7 & 2.8 & $100 \%$ \\
\hline
\end{tabular}

Note: Income figures are in Nigerian currency (Naira). Age categories are in percentage of the respondents

As shown in Table 3 above, as much as $76.8 \%$ of the respondents are under a monthly income category of $\$ 30,000$ and below, of this proportion, $60.1 \%$ are people between the ages of 18 and 49 years, which is $78.3 \%$ of the number of people within this category ( $\$ 30,000.00$ and below). This suggests a large mass of comparatively young people under the lowest income groups, that is, below the minimum wage benchmark, which further suggests that poverty may be predominant among young people in the study area. With the age group of 18 and 49 years consisting of mainly young people and graduates of working age, this results suggests a high rate of unemployment in the study area. Poverty within this age groups may encourage involvement in high risky behaviours, including social crimes, hence could worsen the already critical security situation in the oil producing areas (Bolland, 2003; Chaplin et al., 2014).

As reported in the literature, unemployment among young people is said to promote anti-social behaviours, and has been identified among the reasons for increased crime and insecurity in the rural areas in Nigeria, particularly, the Niger Delta region in Southern Nigeria where crude oil is being extracted (Alabi, 2014; Obi, 2014; Afolabi \& Ehinomen, 2015).

Young people are full of energy, ambitious and their minds are dynamic to changes and anxiety, therefore, a generation of poverty-stricken young people in the rural areas is a big threat to regional and national security. Therefore, it is important that the 
government and oil firms focus more on programmes aimed at reducing unemployment and helping young people to engage in economic activities to improve their income, as this would help in addressing socioeconomic issues including crime, poverty and insecurity

\subsection{Distribution of the respondents based on income groups and family size}

The distribution of the respondents based on income groups and family size is presented in Table 4, below.

Table 4. Distribution of the respondents based on income groups and family size

\begin{tabular}{crcccc}
\hline Income group & \multicolumn{5}{c}{ Family size category } \\
\cline { 2 - 6 } & $\begin{array}{c}1-3 \\
\text { Persons }\end{array}$ & $\begin{array}{c}4-6 \\
\text { Persons }\end{array}$ & $\begin{array}{c}7-9 \\
\text { Persons }\end{array}$ & $\begin{array}{c}10 \text { Persons and } \\
\text { above }\end{array}$ & Total \\
\hline Less than 10000 & 22.1 & 9.4 & 3.8 & 0.2 & 35.5 \\
$10000-20000$ & 8.1 & 15.3 & 3.8 & 0.2 & 27.4 \\
$21000-30000$ & 3.4 & 7 & 3.1 & 0.4 & 13.9 \\
$31000-40000$ & 2.2 & 2 & 1.1 & 0.1 & 5.4 \\
$41000-50000$ & 0.8 & 2.2 & 1.1 & 0 & 4.1 \\
$51000-60000$ & 0.8 & 1.8 & 0.4 & 0.1 & 3.1 \\
$61000-70000$ & 1.3 & 1.1 & 0 & 0 & 2.4 \\
$71000-80000$ & 1.5 & 0.9 & 0 & 0 & 2.4 \\
$81000-90000$ & 0.4 & 0.9 & 0.4 & 0.1 & 1.8 \\
$91000-100000$ & 0.7 & 1.1 & 0.4 & 0 & 2.2 \\
Above 100000 & 0.4 & 0.7 & 0.7 & 0 & 1.8 \\
Total & 41.7 & 42.4 & 14.8 & 1.1 & 100
\end{tabular}

Note: Income figures are in Nigerian currency (Naira). Family size is presented in percentage of respondents within each category.

As indicated in Table 4 above, respondents with a family size of 1-3 people dominate the comparatively low-income categories, using the 30,000.00 Naira national minimum wage as a benchmark, for instance, $33.6 \%$ of the $41.7 \%$ individuals with a family size of 1-3 persons fall within the low-income category, logically suggesting that many young people are within this income group. This corroborates the results in Table 3, indicating a mass of young people within comparatively low-income category. Thus, as already noted above, to ensure a sustainable solution to poverty and insecurity in the oil producing region, it is important that debates and policies are targeted at practical issues of ensuring sustainable employment opportunities for young people who are undoubtedly the prime proponents of most crimes and violent protests in the oil producing areas. These views are also shared by Arowosegbe (2009 and Oluwaniyi (2010).

\subsection{Distribution of the respondents based on income groups and gender}

The distribution of the respondents based on income groups and and gender is presented in Table 5, below. 
Published by Hasanuddin University and Asian Rural Sociology Association

Table 5 Distribution of the respondents based on income groups and gender

\begin{tabular}{cccc}
\hline Income group & Female & Male & Total (\%) \\
\hline Less than 10000 & 15.5 & 20 & 35.5 \\
$10000-20000$ & 8.1 & 19.3 & 27.4 \\
$21000-30000$ & 4 & 9.9 & 13.9 \\
$31000-40000$ & 2 & 3.4 & 5.4 \\
$41000-50000$ & 1.6 & 2.5 & 4.1 \\
$51000-60000$ & 0.7 & 2.4 & 3.1 \\
$61000-70000$ & 0.4 & 2 & 2.4 \\
$71000-80000$ & 0.4 & 2 & 2.4 \\
$81000-90000$ & 0.9 & 0.9 & 1.8 \\
$91000-100000$ & 0.2 & 2 & 2.2 \\
Above 100000 & 1.1 & 0.7 & 1.8 \\
Total & 34.9 & 65.1 & 100 \\
\hline
\end{tabular}

Note: Income figures are in Nigerian currency (Naira). Gender is presented in percentage of respondents within each category

The result in Table 5 above indicates that of the 446 respondents engaged in this study, $65.1 \%$ were male and $34.9 \%$ were female; out of which there are $49.2 \%$ male respondents against $27.6 \%$ female respondents within the minimum income category of $30,000.00$ Naira. This represents $75.6 \%$ of the male and $79.1 \%$ of the female within the proposed minimum wage. The slim disparity in male to female proportion (estimated at 76:79), suggests that comparatively, there might be poorer female population than poor males in the rural areas. In other words, this might suggest comparatively, poverty prevalence or vulnerability to poverty among women in the rural areas. This result corroborates the report by the Nigerian Minister of Women Affairs as published by Daily Post of July, 132013 (Pwanagba, 2013), and the report that poverty is prevalent in the rural areas with women being the worse hit and among the vulnerable groups to its consequences (Iyela \& Ikwuakam, 2015). The finding also relates to the study by Keeni et al. (2018), and suggests that in addition to other measures, the rural people can also volunteer to organize themselves into cooperative groups for eradication of poverty.

\section{Conclusion}

The overall results of this study suggest the prevalence of poverty in oil-producing rural areas in Nigeria. This may not be unconnected with the fact that rural people in these areas seem disconnected from the supposed benefits of their traditional sources of livelihood, and the natural environment which is the primary basis of their livelihood; for instance, land for agriculture (farming), water for fishing, and forest for hunting, lumbering and gathering of wild valuables. In particular, besides visibly poor infrastructural development in the rural areas, findings of this study suggest an obvious impact of oil and gas extraction on agriculture and other traditional sources of livelihood in the rural areas. 
With the findings that a large mass of young people might fall within the low-income category, and since the majority of people in the rural areas depend largely on the natural environment engaging mainly in farming, fishing, hunting and forestry activities, there is a strong indication that farmers, fishermen, hunters and young people are probably among the poorest people in oil producing rural areas in Nigeria. Thus, a significant reduction in environmental pollution would help to sustain the environment, improve agriculture and other sources of livelihood of the rural people. Therefore, the study encourages increased support by the government and oil companies, for agricultural development in the rural areas especially in oil producing areas where the negative effects of crude oil exploration and extraction are obvious. In particular, the government is encouraged to ensure direct financial supports to farmers to boost profitable food production and ensure enabling programmes to enhance effective support and training of rural farmers and fishermen, as well as improved extension services in the rural areas. To achieve this, the government and multinational oil companies can collaborate with agricultural research institutes, academic institutions, financial institutions, insurance firms and farmers' groups or cooperatives. On the other hand, the study encourages people in the oil producing rural areas to organize themselves into cooperative groups which can be as a platform through which they can empower themselves towards tackling poverty among them. With organized cooperatives, the people can also be empowered or get support from the government and other organizations.

Agricultural development would improve the income of rural household, help to reduce poverty, enhance food security, provide employment and help reduce social crimes in the rural areas. This study further encourages increased private sector investment in agriculture in the rural areas by specifically engaging in efficient food crop and animal production, improved food value chain and improved marketing system for agricultural products, as well as investment in agricultural research. In addition, the government and oil companies are encouraged to guarantee efficient wealth distribution, provision of employment and sustainable human empowerment through viable skills acquisition programmes for young people in the rural areas.

In summary, besides the scepticism about the statistical viewpoint of the descriptive analysis, findings of this study clearly suggest existence of socioeconomic disparity, income inequality and prevalence of poverty in oil producing rural areas in Nigeria and provide the basis for further studies. Nevertheless, in an attempt to achieve a comparatively effective measures towards bridging the gaps in socioeconomic and poverty profiles in the rural areas, this study proposes further research works on the subject matter involving comparative studies and complex quantitative methodologies. The study also suggests that similar studies are carried out in other countries where natural resources such as crude oil and gas are being exploited; to enable proffering adequate and sustainable solutions to poverty and other peculiar socioeconomic issues affecting the rural areas.

\section{Acknowledgement}

Authors acknowledge the logistical support from staff of the Federal Polytechnic, Ekowe, Bayelsa State, Nigeria, during the period of this research. 


\section{References}

Adekola, O., Mitchell, G. and Grainger, A. (2015). Inequality and ecosystem services: The value and social distribution of Niger Delta wetland services. Ecosystem Services, 12, 42-54. DOI: https://doi.org/10.1016/j.ecoser.2015.01.005.

Aigbokhan, B. E.(2008). 'Growth, Inequality and Poverty in Nigeria.', ACGS/MPAMS

Discussion Paper, United Nations Economic Commission for africa, 3, February, Addis Ababa, Ethiopia.

Afolabi, B., \& Ehinomen, C. (2015). Rising Youth Unemployment and its Social Economic

Implications for the Growth and Development of the Nigerian Economy. Available at SSRN. http://papers.ssrn.com/sol3/papers.cfm?abstract id=2549284.

Alabi, T. (2014). Youths' Unemployment and Crime Control: An Analysis of Nigerian Experience. European Scientific Journal, 10(2).

Arowosegbe, J. O. (2009). Violence and national development in Nigeria: The political economy of youth restiveness in the Niger Delta. Review of African Political Economy, 36(122), 575-594.

Azaiki, S. (2009). The Evil of Oil. Ibadan, Nigeria: Y-Books (A Division of Associated Book Makers Nigeria Limited.

Bhau, GV. \& Ukpong, I.G. (2018). Perceptions of Environmental Footprints of Oil and Gas Extraction in Southern Nigeria. AGU International of Research in Social Sciences \& Humanities (AGUIJRSSH), 6, 198-208. http://www.aguijrssh.com.

Bello, M. A. \& A. H. Roslan (2010). 'Has Poverty Reduced in Nigeria', European Journal of Sciences, (15)1,

Bolland, J. M. (2003). Hopelessness and risk behaviour among adolescents living in high-

Poverty inner-city neighbourhoods. Journal of adolescence, 26(2), 145-158.

Chaplin, L. N., Hill, R. P., \& John, D. R. (2014). Poverty and materialism: a look at impoverished versus affluent children. Journal of Public Policy \& Marketing, 33(1), 78-92.

Chokor, B. A. (2004). Perception and response to the challenge of poverty and environmental

resource degradation in rural Nigeria: Case study from the Niger Delta. Journal of Environmental Psychology, 24(3), 305-318.

CIA World Fact Book (2018). Nigeria Population below poverty line. http://indexmundi.com.

Updated: $20^{\text {th }}$ January 2018.

CIA (2010). World Fact Book: Country Outlook-Nigeria, viewed 1 April 2011, http://www.cia.gov.

Ekpebu, I. D., \& Ukpong, I. G. (2012). Rethinking Agricultural Development in Nigeria:

Paradox of Oil Wealth. Authorhouse: Bloomington, USA.

Earthtrends (2003): Economic Indicators: Nigeria, viewed 2 April 2011, http://earthtrends.wri.org.

Fan, S., Hazell, P., \& Thorat, S. (2000). Government spending, growth and poverty in rural

India. American Journal of Agricultural Economics, 82(4), 1038-1051. 
Gaughran, A. (2009). Oil Industry has brought Poverty and Pollution to Niger Delta, from http://www.amnesty.org. [Assessed 21 Jan 2015].

Gibson, J., \& Rozelle, S. (2003). Poverty and Access to Roads in Papua New Guinea*.

Economic development and cultural change, 52(1), 159-185.

Huang, Y. \& Ukpong, I.G. (2019). Issues of Water Resource Management in China:

Implications on Agriculture and Food Security in the Guangxi Province of South China. J. Asian Rur. Stud. 3(1): 70-84.

Idemudia, U. (2014). Oil companies and sustainable community development in the Niger

Delta, Nigeria: the issue of reciprocal responsibility and its implications for corporate citizenship theory and practice. Sustainable Development, 22(3), 177-187.

Idemudia, U. (2010). Corporate social responsibility and the rentier Nigerian state: Rethinking the role of government and the possibility of corporate social development in the Niger Delta. Canadian Journal of Development Studies/Revue canadienne d'études du développement, 30(1-2), 131-151.

Ita, M. N., Ukpong, I. G. \& Ekpebu, I. D. (2013). Budgetary Allocations to the Agricultural Sector in Nigeria: Implications on Investment and Productivity. Journal of Agricultural Science, Canada. 5(11), 49-53. DOI: 10.5539/jas.v5n11p.

Iyela, A. \& Ikwuakam, O.T. (2015). Poverty coping strategies of Rural Women dwellers of Batagarawa Local Government Area of Katsina State, Nigeria. Mediterranean Journal of Social Sciences, 6(6 S4): 296-306. Doi: 10.5901/mjss.2015 v6n6s4p296.

Keeni, M., Takashino, N., Nongkynrih, A.K., and Fuyuki, K. (2018). Women Empowerment in a Rural Matrilineal Society of Meghalaya, India. J. Asian Rur. Stud. 2(2): 144-152.

NDRDMP (2006), Niger Delta Region Development Master Plan, Niger Delta Development Commission, Port Harcourt, Nigeria.

Obi, C. (2014). Oil and the Post-Amnesty Programme (PAP): what prospects for sustainable development and peace in the Niger Delta? Review of African Political Economy, 41(140), 249-263.

Oluwaniyi, O. O. (2010). Oil and youth militancy in Nigeria's Niger Delta region. Journal of Asian and African Studies, 45(3), 309-325.

Onuoha, F. (2007). Poverty, pipeline vandalisation/explosion and human security: integrating disaster management into poverty reduction in Nigeria. African Security Studies, 16(2), 94-108.

Oyefusi, A. (2008). Oil and the probability of rebel participation among youths in the Niger

Delta of Nigeria. Journal of Peace Research, 45(4), 539-555.

Pwanagba, A. (2013). 70\% of Nigerian Women are living below the Poverty lineMinister.

DailyPost, Nigeria News, July 13, 2013. Available online via: dailypost.ng/2013/. Accessed January 11, 2013.

Ukpong, I.G. (2019). Econometrics of Environmental Valuation: The Bayesian Inferences on Willingness to pay Estimations. Review of Agricultural and Applied Economics (RAAE), 22(2): 03-09. DOI: 10.15414/raae.2019.22.02.03-09. 
Ukpong, I.G. (2011). Empirical Analysis of the Impact of Agriculture on Poverty Reduction in Nigeria. MSc Dissertation submitted to the School of Agriculture, Policy and Development. University of Reading, United Kingdom. September, 2011 (Unpublished).

Ukpong, I.G., Ekpebu, I.D. \& Ofem, N.I. (2013). Cointegration inferences on issues of

Poverty and Population Growth in Nigeria. Journal of Development and Agricultural Economics, 5(7): 277-283. DOI: 10.5897/JDAE12.151.

Ukpong, I. G. \& Ibrahim, M. K. (2014). Implication of Leadership change on Poverty trends in Nigeria. International Affairs and Global Strategy, 20: 6-11.

Ukpong, I.G, Inyeinyang, M.M \& Omovwohwovie, E.E. (2017). Impact of the Oil and Gas Industry in Nigeria: An evaluation of cases in the Niger delta. Journal of Biopesticides and Environment, 4(2), 22-28.

Ukpong, I.G. \& Obok, E. (2018). Implications of Crude Oil extraction on Agriculture and Livelihood in Oil producing Rural Communities in Nigeria. Review of Agricultural and Applied Economics (RAAE), 21(2): 71-77. Doi: 10.15414/raae/ 2018.21.02.71-77.

Ukiwo, U. (2007). From "pirates" to "militants": A historical perspective on anti-state and anti-oil company mobilization among the Ijaw of Warri, Western Niger Delta. African Affairs, 106(425), 587-610. 